\title{
ANALISIS RESPON MAHASISWA TERHADAP MEDIA AUTOPLAY DENGAN METODE MEA SEBAGAI MEDIA PEMBELAJARAN MATAKULIAH GENETIKA DI IKIP BUDI UTOMO MALANG
}

\author{
Primadya Anantyarta ${ }^{1}$, Ririn Listya Ika Sari ${ }^{2}$ \\ ${ }^{1,2}$ IKIP Budi Utomo Malang, J1. Simpang Arjuna No. 14B, Malang \\ e-mail: anantyarta@yahoo.co.id
}

\begin{abstract}
One of the efforts in accommodating 21st century learning in IKIP Budi Utomo Malang, especially in Biology Education Program in Genetics Subject is with the development of Auto Play media with MEA (Means-Ends-Analysis) method. This study aims to produce products in the form of learning media based on Genetics Auto Play with MEA method. This development research uses Research and Development (R \& D) method with 4D development model which has Define, Design, Develop, and Disseminate stages. In this research is done up to development stage and especially on small scale test on 10 students of biology education program IKIP Budi Utomo Malang. The result of student response analysis stated that the developed media is included in good enough category $(88,57 \%)$. For media benefit criteria included in highly valid category $(89.5 \%)$, media display criteria fall into very valid category $(89.5 \%)$, and media material presentation criteria fall into very valid category $(86.5 \%)$.
\end{abstract}

Keywords: Autoplay Media, MEA Method.

\section{PENDAHULUAN}

Selama ini sistem pembelajaran di Indonesia pada umumnya masih dilakukan secara manual yaitu dengan menggunakan media konvensional. Media tersebut dirasa kurang menarik karena orang mulai bosan dengan sistem pembelajaran yang monoton dan kurang inovatif (Sukmawati, 2015). Sudah seharusnya sistem pembelajaran di Indonesia mengikuti perkembangan dan perubahan abad 21 yang ditandai dengan penggunaan teknologi informasi dalam pembelajaran.

Pembelajaran abad 21 juga seharusnya sudah dikembangkan di Perguruan Tinggi. IKIP Budi Utomo Malang sebagai salah satu Lembaga Perguruan Tinggi juga diharapkan dapat mengembangkan dan menerapkan pembelajaran yang sesuai untuk abad 21. Salah satu Program Studi di IKIP Budi Utomo Malang yaitu Program Studi Pendidikan Biologi, memiliki banyak matakuliah dengan karakter abstrak (karena berhubungan dengan proses kehidupan) sehingga sulit dipahami tanpa adanya bantuan media pembelajaran. Salah satu matakuliah pada Program Studi Pendidikan Biologi yang bersifat abstrak adalah matakuliah Genetika.

Pembelajaran genetika saat ini masih menjadi kendala diberbagai Lembaga Perguruan Tinggi. Hal tersebut dikarenakan sebagian besar mahasiswa menganggap genetika sebagai ilmu yang sulit atau tidak mudah dipahami. Di samping itu, mahasiswa beranggapan bahwa materi genetika terlalu teoritis, kurang bersifat kontekstual, dan pemanfaatan media kurang optimal. Sehingga, pemahaman dan penguasaan konsep mahasiswa relatif lemah (Dikti, 2007).

Kebanyakan mahasiswa masih memandang materi genetika dianggap paling sukar, abstrak, dan begitu menakutkan. Akhirnya penguasaan mahasiswa terhadap materi genetika secara umum sangat kurang. Media yang digunakan oleh dosen pun sangat terbatas, sehingga mahasiswa cenderung 
kurang bersemangat dan sulit untuk belajar ataupun berdiskusi satu dengan lainnya.

Berdasarkan hasil wawancara dengan dosen pengampu matakuliah genetika dapat disimpulkan bahwa selama ini proses pembelajaran matakuliah genetika belum memanfaatkan media pembelajaran secara maksimal. Hal ini mengakibatkan pemahaman mahasiswa khususnya tentang konsep Genetika menjadi kurang.

Salah satu upaya untuk mengatasi masalah tersebut dan sekaligus dapat mengakomodasi pembelajaran abad 21 di IKIP Budi Utomo Malang pada Program Studi Pendidikan Biologi khususnya pada matakuliah Genetika yaitu dengan mengembangkan media dan metode pembelajaran inovatif. Media dan metode pembelajaran inovatif yang dikembangkan adalah media pembelajaran Autoplay dengan metode MEA (Means Ends Analysis).

Media pembelajaran merupakan bagian dari sumber belajar yang merupakan kombinasi antara perangkat lunak (bahan belajar) dan perangkat keras (alat belajar) (Muhson, 2010). Penggunaan media dalam proses pembelajaran merupakan salah satu upaya untuk menciptakan pembelajaran yang lebih bermakna dan berkualitas. Menurut Latuheru (1988) dalam Sukmawati (2015), penggunaan media dalam proses pembelajaran bertujuan agar proses pembelajaran dapat berlangsung secara tepat guna dan berdaya guna sehingga mutu pendidikan dapat ditingkatkan.

Salah satu media inovatif yang dapat dikembangkan adalah media Autoplay. Menurut Masruri (2011) media Autoplay merupakan sebuah software yang dapat digunakan untuk membuat suatu presentasi secara professional. Software ini dapat mengintegrasikan teks, gambar, dan video dengan baik. Aplikasi Autoplay memungkinkan pengguna membuat autorun presentation dengan berbagai macam file seperti: video, foto, power point, Ms.Exel, Ms.Word, flash dan berbagai macam file lainnya.

Selain pengembangan media Autoplay juga akan dikombinasikan dengan penggunaan metode MEA. Metode MEA (Means Ends Analysis) bisa diartikan sebagai suatu metode untuk menganalisis permasalahan melalui berbagai cara untuk mencapai tujuan akhir yang diinginkan. MEA merupakan metode penyelesaian masalah yang terdiri dari langkah identifikasi tujuan yang akan dicapai, analisis situasi saat ini, dan langkah untuk mengurangi perbedaan antara kedua kondisi tersebut (Slavin, 2011). Metode MEA memfokuskan untuk membagi-bagi permasalahan menjadi bagianbagian tertentu dari permasalahan tersebut untuk mencapai tujuan yang diinginkan.

MEA adalah suatu proses untuk memecahkan masalah ke dalam dua atau lebih sub tujuan. Sehingga metode ini merupakan pengembangan dari metode pemecahan masalah (problem solving), hanya saja setiap masalah yang dihadapi dipecah menjadi sub-sub masalah yang lebih sederhana kemudian pada akhirnya dikoneksikan kembali menjadi sebuah tujuan utama.

Pembelajaran dengan metode MEA menuntut mahasiswa untuk aktif dalam kegiatan pembelajaran. Diharapkan pengembangan media pembelajaran Autoplay dengan metode MEA tersebut dapat menjadi salah satu upaya dalam mengakomodasi pembelajaran abad 21 bagi mahasiswa IKIP Budi Utomo Malang khususnya pada Matakuliah Genetika Program Studi Pendidikan Biologi.

\section{METODE PENELITIAN}

Metode yang digunakan dalam penelitian ini adalah metode satu tahap penelitian pengembangan, yaitu ujicoba produk (media pembelajaran genetika) yang dilakukan 
setelah produk selesai disusun. Subjek penelitian dalam ujicoba media pembelajaran adalah mahasiswa Pendidikan Biologi angkatan 2014 di IKIP Budi Utomo Malang yang berjumlah 10 orang. Instrumen yang digunakan untuk mengetahui respon mahasiswa terhadap media pembelajaran genetika yang dikembangkan dengan menggunakan Autoplay dengan metode MEA berupa angket tertutup. Angket tertutup menggunakan format empat point dari skala Likert, dimana alternatif respon adalah sangat setuju (SS), setuju (S), tidak setuju (TS), sangat tidak sejutu (STJ).

Berikut adalah lembar angket respon mahasiswa terhadap pengembangan media Autoplay dengan metode MEA.

Tabel 1. Lembar validasi Aspek Tampilan pada Media Pembelajaran Autoplay

\begin{tabular}{|c|c|c|c|c|c|}
\hline No & Pernyataan & SS & $\mathbf{S}$ & TS & STS \\
\hline 1 & Teks atau tulisan pada media ini mudah dibaca. & & & & \\
\hline 2 & Gambar yang disajikan jelas atau tidak buram. & & & & \\
\hline 3 & $\begin{array}{l}\text { Gambar yang disajikan sudah sesuai (tidak terlalu banyak dan tidak terlalu } \\
\text { sedikit) }\end{array}$ & & & & \\
\hline 4 & Adanya keterangan pada setiap gambar yang disajikan dalam media ini. & & & & \\
\hline 5 & Gambar yang disajikan menarik. & & & & \\
\hline 6 & Gambar yang disajikan sesuai dengan materi. & & & & \\
\hline
\end{tabular}

Tabel 2. Lembar validasi Aspek Penyajian Materi pada Media Pembelajaran Autoplay

\begin{tabular}{|c|c|c|c|c|c|}
\hline No & Pernyataan & SS & $\mathbf{S}$ & TS & STS \\
\hline 1 & $\begin{array}{l}\text { Media ini menjelaskan suatu konsep menggunakan ilustrasi masalah yang } \\
\text { berkaitan dengan kehidupan sehari-hari. }\end{array}$ & & & & \\
\hline 2 & $\begin{array}{l}\text { Media ini menggunakan contoh-contoh soal yang berkaitan dengan masalah } \\
\text { kehidupan sehari-hari. }\end{array}$ & & & & \\
\hline 3 & $\begin{array}{l}\text { Jika dalam proses pembelajaran menggunakan media ini saya menghadapi } \\
\text { masalah, maka saya berani bertanya dan mengemukakan masalah yang saya } \\
\text { hadapi kepada dosen. }\end{array}$ & & & & \\
\hline 4 & $\begin{array}{l}\text { Penyajian materi dalam media ini mendorong saya untuk berdiskusi dengan } \\
\text { teman-teman yang lain. }\end{array}$ & & & & \\
\hline 5 & $\begin{array}{l}\text { Penyajian materi dalam media ini berkaitan dengan materi biologi yang lain atau } \\
\text { dengan matakuliah yang lain dalam pemecahan masalah dan penerapannya. }\end{array}$ & & & & \\
\hline 6 & Saya dapat memahami materi dengan mudah. & & & & \\
\hline 7 & Materi yang disajikan dalam media sudah runtut. & & & & \\
\hline 8 & Saya dapat mengikuti kegiatan belajar tahap demi tahap dengan mudah. & & & & \\
\hline 9 & Saya dapat dengan mudah memahami kalimat yang digunakan dalam media ini. & & & & \\
\hline 10 & Tidak ada kalimat yang menimbulkan persepsi ganda dalam media ini. & & & & \\
\hline 11 & Saya dapat memahami lambang yang digunakan pada media ini. & & & & \\
\hline 12 & Saya dapat memahami istilah-istilah yang digunakan dalam media ini. & & & & \\
\hline 13 & Contoh soal yang digunakan dalam media ini sudah sesuai dengan materi. & & & & \\
\hline
\end{tabular}

Tabel 3. Lembar validasi Aspek Manfaat dari Media Pembelajaran Autoplay

\begin{tabular}{|c|c|c|c|c|c|}
\hline No & Pernyataan & SS & $\mathbf{S}$ & $\mathbf{T S}$ & STS \\
\hline 1 & Saya dapat memahami materi genetika menggunakan media ini dengan mudah. & & & & \\
\hline 2 & Saya merasa lebih mudah belajar dengan menggunakan media ini. & & & & \\
\hline 3 & Saya sangat tertarik menggunakan media ini. & & & & \\
\hline 4 & Dengan menggunakan media ini saya lebih tertarik dalam belajar genetika. & & & & \\
\hline 5 & $\begin{array}{l}\text { Dengan adanya ilustrasi disetiap awal materi dapat memberikan motivasi untuk } \\
\text { mempelajari materi genetika. }\end{array}$ & & & & \\
\hline 6 & Saya lebih rajin belajar dengan menggunakan media ini. & & & & \\
\hline
\end{tabular}




\section{HASIL DAN PEMBAHASAN}

Hasil uji coba pengembangan media pembelajaran, meliputi hasil respon mahasiswa terhadap media pembelajaran berbasis Auto-play dengan metode MEA.

Instrumen yang digunakan untuk mengetahui respon mahasiswa terhadap media pembelajaran genetika yang dikem- bangkan berupa angket tertutup. Angket penilaian media tersebut memuat tiga aspek yaitu aspek tampilan, aspek penyajian materi dan aspek manfaat media.

Berikut adalah hasil uji coba produk skala kecil dengan mengetahui respon mahasiswa terhadap media Autoplay dengan metode MEA.

Tabel 4. Hasil Uji Coba Skala Kecil Media Autoplay dengan Metode MEA

\begin{tabular}{ccccc}
\hline \multirow{2}{*}{ Mahasiswa } & \multicolumn{3}{c}{ ASPEK PENILAIAN } & \multirow{2}{*}{ RATA-RATA } \\
\cline { 2 - 4 } & Tampilan & Penyajian Materi & Manfaat & 3.46 \\
1. & 3.67 & 3.54 & 3.17 & 3.22 \\
2. & 3.17 & 3.15 & 3.33 & 3.62 \\
3. & 3.67 & 3.54 & 3.67 & 3.57 \\
4. & 3.67 & 3.54 & 3.5 & 3.76 \\
5. & 3.83 & 3.62 & 3.83 & 3.46 \\
6. & 3.67 & 3.38 & 3.33 & 3.87 \\
7. & 4.00 & 3.62 & 4.00 & 3.65 \\
8. & 3.67 & 3.62 & 3.67 & 3.35 \\
9. & 2.83 & 3.54 & 3.67 & 3.47 \\
10. & 3.67 & 3.08 & 3.67 & 3.54 \\
\hline Rata-rata & 3.58 & 3.46 & 3.58 & $\mathbf{8 8 . 5 7 \%}$ \\
\hline Persentase & $\mathbf{8 9 , 5 \%}$ & $\mathbf{8 6 , 5 \%}$ & $\mathbf{8 9 , 5 \%}$ & Sangat Valid \\
\hline Ket & Sangat Valid & Sangat Valid & Sangat Valid & \\
\hline
\end{tabular}

Berikut adalah grafik hasil uji coba pembelajaran Autoplay dengan metode MEA produk skala kecil dengan mengetahui yang ditunjukkan pada Tabel 4 diketahui respon mahasiswa terhadap media Autoplay bahwa media yang dikembangkan ini terdengan metode MEA. Berdasarkan hasil masuk dalam kategori sangat valid dengan analisis res-pon mahasiswa terhadap media persentase sebesar 88,57\%.

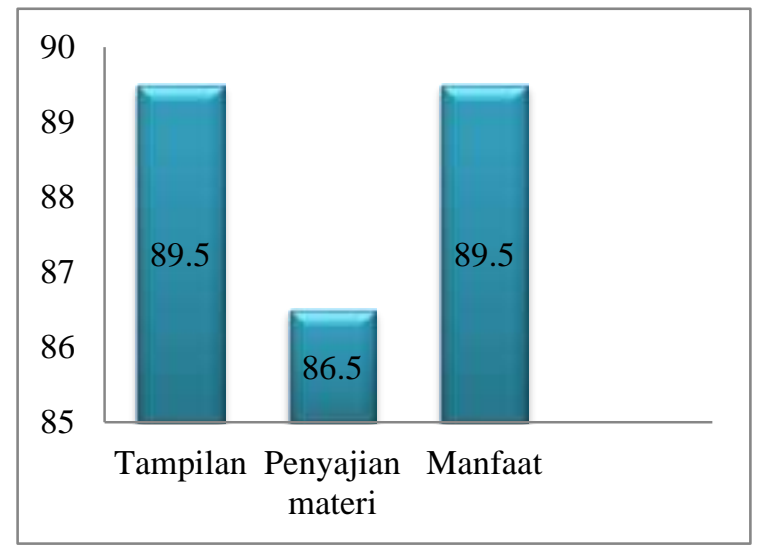

\section{Gambar 1. Grafik Hasil Uji Coba Skala Kecil Media Autoplay dengan Metode MEA}

Pada aspek tampilan desain media pembelajaran termasuk dalam kategori sangat valid yaitu dengan persentase sebesar $89,5 \%$, aspek penyajian materi media pembelajaran termasuk dalam kategori sangat valid, yaitu dengan persentase sebesar $86,5 \%$, dan aspek manfaat media pembelajaran termasuk dalam kategori sangat valid yaitu dengan persentase sebesar $89,5 \%$. 
Media Autoplay bertujuan menyampaikan informasi yang merupakan gabungan dari teks, grafik, suara, video, dan animasi. Sedangkan metode MEA menekankan pada keaktifan mahasiswa dengan langkahlangkah mengidentifikasi tujuan dan informasi dari satu permasalahan kemudian mengidentifikasi serta mereduksi perbedaan dengan membentuk sub-tujuan sehingga mempengaruhi kemampuan menghubungkan konsep dalam permasalahan.

Hasil penelitian ini sejalan dengan penelitian Alfan (2015) yang menunjukkan respon siswa terhadap media pembelajaran Autoplay sangat baik pada matapelajaran memperbaiki CD Player. Penelitian lain oleh Pratama \& Agung (2017) juga menyimpulkan bahwa bahwa respon siswa terhadap media pembelajaran berbasis Autoplay pada mata pelajaran menerapkan Konsep Elektronika Digital dan Rangkaian Elektronika Komputer di SMK Negeri 1 Driyorejo sebesar $86,85 \%$ dan dikategorikan "sangat baik".

\section{SIMPULAN DAN SARAN}

Hasil penelitian menunjukkan bahwa respon mahasiswa untuk media pembelajaran yang dikembangkan berada pada kriteria cukup baik dengan persentase sebesar $88,57 \%$. Saran dalam penelitian ini adalah perlu lebih banyak dikembangakannya media pembelajaran inovatif lain yang sesuai dengan pembelajaran abad 21 .

\section{RUJUKAN}

Alfan, M., Edy S. 2015. Perbandingan Media Pembelajaran (Autoplay Media Studio) Sebagai alat Bantu Pembelajaran Memperbaiki CD Player Siswa Kelas XI di SMK Negeri 3 Surabaya. Jurnal Pendidikan Teknik Elektro Vol 04 No 01 Hal 39-47.

Depdiknas. 2003. Media Pembelajaran. Jakarta :Depdiknas.

Masruri, H. 2011. Presentasi Interaktif dengan Autoplay Media Studio. Jakarta: PT. Elex Media Komputindo.

Pratama, Y. \& Agung, Y.A. 2017. Pengembangan Media Pembelajaran Berbasis Autoplay Pada Mata Pelajaran Menerapkan Konsep Elektronika Digital dan Rangkaian Elektronika Komputer di SMK Negeri 1 Driyorejo. Jurnal Pendidikan Teknik Elektro. Volume 06 Nomor 01.

Sanaky, H.AH. 2009. Media Pembelajaran. Yogyakarta: Safiria Insania Press

Slavin, R.E. 2011. Psikologi Pendidikan: Teori dan Praktik. Jakarta: PT Indeks.

Sukmawati, 2015. Pengembangan Aplikasi Pembelajaran Biologi SMP Berbasis Android Untuk Bekal Menghadapi UAN Di SMP Islam Bakti 1 Surakarta. 